\title{
CSDP: The Strategic Perspective
}

\author{
Sven Biscop and Per M. Norheim-Martinsen
}

\section{European Studies Discover Strategy}

For a long time, strategic studies and European studies appeared to mutually ignore if not disdain each other. During the Cold War, strategic studies concentrated on the exercise of hard power as an instrument of foreign policy. Their natural focus was the military strategy of the United States and the Soviet Union. It came equally naturally to ignore the European Economic Community (EEC), which except for the informal consultation mechanism of European Political Cooperation (EPC) did not venture into the realm of foreign policy, let alone security and defence policy. European studies themselves for the most part did not look at the EEC as an actor in the field of security and defence policy, turning instead to conceptualizations of the Community as a "civilian power" or, more recently, a "normative power" (Bull 1982; Duchêne 1972; Telo 2006; Whitman 1998; Manners 2002; 2006).

Even when the European Union came into existence and with it the Common Foreign and Security Policy (CFSP), to be followed by the European, now Common Security and Defence Policy (ESDP/CSDP), many scholars focused their efforts on trying to explain how these developments did not detract from Europe's status as a civilian or normative power (Stavridis 2001). Others, who thought these developments did just that, offered recommendations for how to put things right, as if somehow it would be wrong for the EU to venture onto another path and become a fully-fledged actor in the field of security and defence (see e.g. Manners 2009 and Smith 2006). Strategic studies scholars meanwhile did not take the tentative steps of the CFSP and CSDP very seriously (see e.g. Heisbourg 2004; Toje 2005; Wyllie 2006).

The cause of this state of affairs is that both strategic studies and European studies scholars for the most part have a very narrow interpretation of the notion of strategy. Too often, strategy is understood as pertaining only to "the application of military power to achieve political objectives" (Baylis et al. 2002, p.3). If analyzed through this lens, the EU obviously is less well developed than other, unitary actors. Many EU studies scholars reject such an exclusively military-oriented approach for ideological reasons or because, less obviously, strategic studies are associated with an exclusively realist approach to foreign policy. Many strategic studies scholars, on the other hand, feel that the EU is too insignificant an actor in the field of security and defence to merit their attention - although every classic author about strategy actually warns against underestimating the enemy. However, military force, even coercive instruments in the broader sense, are but one of a much broader range of instruments at the disposal of a foreign policy actor. Admittedly the most dramatic tool, force is also the instrument of last resort - an actor that has no other available instruments, would not last very long. Since on the international scene the EU, a state-like actor, is much more than a military actor no useful analysis of it can be limited to the military dimension of what it does. 
That strategy must be understood as a broader concept is, in fact, apparent from what is often referred to as the standard definition itself. Clausewitz, in Howard and Paret's translation, defines strategy as: "the use of engagements for the object of the war" (Clausewitz 1976 [1832]). This definition may at first sight seem outdated and too narrow. Yet, as Colin Gray argues, Clausewitz's original definition easily lends itself to an "expansion of domain so as to encompass policy instruments other than the military" (Gray 1999, p. 17). As he goes on:

The cardinal virtue of the Clausewitzian definition of strategy is that it separates those things that must be separated. Anyone who reads, understands and accepts the Clausewitzian definition will never be confused about what is strategic and what is not. (...) Armed forces in action, indeed any instrument of power in action, is the realm of tactics. Strategy, in contrast, seeks to direct and relate the use of those instruments to policy goals. Clausewitz, therefore, is crystal-clear in distinguishing between action and effect and between instrument and objective.

Basil Liddell-Hart also argues that Clausewitz has been consistently misinterpreted as encouraging the subordination of politics to the object of war. Strategy should be interpreted rather as "the art of distributing and applying military means to fulfil the ends of policy" (Liddell-Hart 1967, p. 335).

The essence of strategy ultimately boils down to the extent to which any instruments of power military as well as non-military - further a perceived political end. Military power is not strategic per se. It is the linking of military power to political purpose that is strategic. Hence, the EU's perceived focus on "soft power" or non-military instruments is not necessarily less strategic than the manifestly more militaristic approach demonstrated, for example, by the United States. Strategy is about ends and means, or specifically how they are linked. From a strategic perspective, therefore, we are interested in whether the EU, or any other actor for that matter, has the capacity to formulate shared political ends in a strategy, and whether it can generate relevant means, but also has the resolve or strategic culture, to act to further these ends. When applying this definition to the EU as an international actor, strategy refers to the EU's comprehensive foreign policy strategy, covering all dimensions of external action, from aid and trade to diplomacy and the military. Such a foreign policy strategy is of course not an operational piece of paper, but has to be translated into sub-strategies, policies and actions. It has what Alyson Bailes (2005, p.14) has called an inspiring function vis-à-vis policy-making. The military dimension thus is no more - and no less - than a sub-strategy to the overall foreign policy strategy. The latter serves as a reference framework for day-to-day policymaking in a rapidly evolving and increasingly complex international environment, and guides the definition of the means - in casu the civilian and military capabilities - that need to be developed.

Clearly, this updated definition of strategy can no longer be exclusively tied to the realist school: a strategy inspired by a realist world view is just one option out of many that any international actor can follow. The 2003 European Security Strategy (European Council 2003, referred to as ESS hereafter), with its focus on a preventive, holistic and multilateral approach, testifies to this. Insofar as strategy concerns foreign policy in its entirety, civilian or normative power should not be seen as being in contradiction to the development of military power by the EU, but as 
complementary dimensions of a single grand strategy. As Jolyon Howorth (2010a, p.465) forcefully puts it:

The debate over 'normative power Europe' is largely an irrelevance. Of course the EU will continue to pursue norms-based effective multilateralism; of course it will continue to promote a world in which human rights, human security, international institutions and international law will replace the jungle. But if those objectives are actually to be achieved, the EU must have the entire range of policy instruments, including a significant measure of hard power. ESDP exists. It exists for very powerful historical reasons. It functions as a vital underpinning of the EU's normative ambitions around the world. The EU is, and will remain, a military actor - albeit a military actor of a new and very different type.

This modernized, broader definition of strategy, we would argue, is not so broad as to validate Hew Strachan's (2005, p.34) view that "the word 'strategy' has acquired a universality which has robbed it of meaning, and left it only with banalities". Rather it allows for the useful application of the strategic perspective on the EU, which as it has become an actor in its own right in all fields of foreign and security policy, can no longer be ignored by strategists. Several authors have also started to look at the EU through the strategic lens in recent years, particularly since the adoption of the European Security Strategy in 2003 (see e.g. Biscop 2005; Biscop and Andersson 2008; Engelbrekt and Hallenberg 2008). Whereas most theoretical schools capture only part of the EU, the strategic perspective by contrast offers an analytical approach rather than a theory, which can be applied regardless of the different IR schools and their proselytes. The strength of this approach is that it is, indeed, able to accommodate realism as well as less stateoriented theories.

Having argued in this section that the strategic perspective can be applied to the EU, in section 2 we will explain why this is relevant. In section 3 we will then approach the EU from the strategic perspective. The first question to be addressed is: does the EU actually have a strategy (3.1)? It is not sufficient to have a strategy however - one must also apply it. The next question, therefore, is whether the EU can be considered a strategic actor, i.e. an actor who not only consciously sets long-term strategic objectives, but actively pursues those and acquires the necessary means to that end (3.2). If a strategic actor is effective, i.e. if it is successful in achieving its strategic objectives, it can be considered a power. If the EU is a strategic actor, related questions can be asked regarding its strategic culture: what is its content, how strong is it, and what impact does it have on policy and action (3.3)?

\section{The Importance of the Strategic Perspective}

For some time, scholars in the strategic studies tradition have expressed regrets that their field has become a marginalised subfield of security studies. Strategic studies today, in the words of Strachan, "flourish more verdantly in schools of business studies than in departments of international relations" (Strachan 2005, p. 34; see also Betts 1997). Yet rather than rejecting strategy as a term emptied of meaning altogether, we argue that it is more fruitful to re- establish 
what is arguably the core of the strategic concept: the instrumental focus on ends and means, and the strategic link between them. Incidentally, a brief look into the history of strategic studies reveals that this link has, at times, also been missing from within its own field. A telling example is Michael Howard's account of the lost dimensions of strategy, and his critique of the belief, central to the 1970s' MAD and NUT nuclear strategists, that technology could somehow remove strategy's political or operational dimensions (Howard 1983). The more recent focus on Network Centric Warfare (NCW), by some seen to amount to a Revolution in Military Affairs (RMA), would seem to offer a striking parallel, insofar as technology again has proven insufficient for dealing with the challenges of the day in Afghanistan and beyond.

In fact, a renewed focus on the core tenets of strategy would not only seem to have much to offer to the study of the effectiveness of hard power, but also to security studies in general, which has seen a massive expansion beyond its origins in strategic studies. The field of security studies today reflects a 20-year-old debate between those who wants to restrict the use of the term security to traditional threats (e.g. Deudney 1990; Freedman 1998; Walt 1991, 1998), and those who argue for an expansion into various new domains, such as human rights, environmental issues, etc (e.g. Ayoob 1995; Buzan, de Wilde, and Waever 1998; Haftendorn 1991; Katzenstein 1996; Krause and Williams 1997). Although there may be various reasons to limit the expansion of the security agenda beyond the traditionalist view (see e.g. Huysmans 1995, 1998; Waever 1995, 1998), the current state of play, nevertheless, is one in which almost any political or societal challenge can be - and is - defined as a security threat. Or, to paraphrase Alexander Wendt: security is what states, and a growing number of actors within and beyond the state, make of it (Wendt 1992). In this context, the strategic perspective may help us in our assessment of the measures that various actors - including a non-state actor like the EU - take to further what they perceive to be in their best interest.

This perspective has much to offer the analysis of the EU. First, by focusing on the relationship between ends and means rather than the character of the means (i.e. civilian or military) as the defining element of the EU as an international actor, the categorisation, and hence the problems of accommodating different forms of power projection inherent to the ongoing debates on what kind of actor or power the EU is or should be, are avoided. Secondly, by focusing on the means as relative to the ends they serve, we avoid the military bias, which has dominated some of the previous analyses of CFSP/CSDP that have taken a strategic perspective. Thirdly, singling out three central elements - strategy, actorness and culture - allows an assessment of developments against three more or less clearly identifiable benchmarks. Accordingly, it is possible to use the strategic perspective to monitor developments, while at any given point in time being able to come up with some conclusions regarding the status of the EU as an international actor. As such, actorness is treated as a matter of "level of" rather than "either/or" (cf. Hill 1993). The utility of taking a strategic perspective, therefore, lies not so much in explaining how and why institutions and policies came into existence, but in assessing and explaining their effectiveness, while opening up to comparisons with other actors and generating policy-relevant insights and recommendations.

Finally, by also including strategic culture as a central element in the analysis, we are able to accommodate some of the ideational or normative features of the EU. As Giovanni Grevi argues, 
"in the case of the EU - a collective international actor bringing together 27 member states - the claim to 'actorness' depends crucially on its internal institutional and normative features" (Grevi 2009). Indeed, within the strategic studies tradition, the idea that an actor, whether a state or another polity, acts within the context of its identity(/ies), history, norms, ideas, etc, has been subject to a 30-year-old debate on strategic culture. However, as the concept has received renewed interest in the EU context, the debate has largely circled around whether the EU has a strategic culture or not (Cornish and Edwards 2001, 2005; Heiselberg 2003; Hyde Price 2004; Martinsen 2004; Matlary 2006; Meyer 2006; Norheim-Martinsen 2007; Rynning 2003; Toje 2008). This is a question that seems to defy a contemporary understanding of strategic culture, and, therefore, does not benefit from how strategic culture can be used as an analytical tool. Essentially, strategic culture - as actorness - is not a question of "either/or", but ought to be treated as a precondition or a set of boundaries within which any actor operates, since culture equals context - i.e. all behaviour is ultimately cultural behaviour (Gray 1999). This reflects the original understanding of strategic culture, which remains valid after a protracted theoretical debate during the 1990s between advocates of the first and third generation of strategic culture studies (see below). In line with the understanding of culture as context, we hold that studying certain specific elements of an EU strategic culture may help identify some fundamental parameters that may constrain or facilitate its room for manoeuvre. Indeed, one way through which strategic cultures are readily expressed and consciously (re)shaped is through the concept of strategic narratives, which has received considerable interest in the strategic literature (see e.g. Freedman 2006). This means that we need not only look into the actual contents of EU strategic documentation, but also the overall storyline or strategic cultural roots that are consciously or unconsciously conveyed through the strategic narrative. We shall start by looking at the contents, and return to strategic culture towards the end of the chapter.

\section{The Strategic Perspective Applied to the EU}

\subsection{A Strategy?}

Applying the strategic perspective to the EU, we must first establish whether the EU has a written strategy, i.e. a document which starting from its values and interests and from an assessment of the global environment, defines the long-term overall objectives to be achieved, the basic categories of instruments to be applied to that end, and the means which that requires. This naturally leads us to the ESS, the core of which can be summarized in three principles.

The first is prevention: "we should be ready to act before a crisis occurs. Conflict prevention and threat prevention cannot start too early", the ESS states. A permanent strategy of prevention and stabilisation, addressing the root causes of threats and challenges, aims to prevent conflict so that, ideally, coercion and the use of force will not be necessary. Addressing the root causes means to close the gap, both within and between countries, between the haves and the have-nots in terms of access to the core public goods: security, prosperity, freedom and well-being. This gap generates feelings of frustration and marginalization on the part of those that are excluded economically or politically, radicalisation and extremism of various kinds, social and economic instability, massive migration flows, and tension and conflicts within and between States. 
Effective prevention is an enormous challenge, for it means addressing a much wider range of issues, at a much earlier stage, across the globe, because as the ESS says "the first line of defence will often be abroad".

Closing the gap between haves and have-nots necessarily demands a holistic approach, for the security, economic, political and social dimensions are inextricably related - an individual cannot enjoy any one core public good unless having access to them all - and all are present, in differing degrees, in all threats and challenges. In the ESS: "none of the new threats is purely military, nor can any be tackled by purely military means. Each requires a mixture of instruments". Therefore every foreign policy must simultaneously address all dimensions, making use in an integrated way of all available instruments: "Diplomatic efforts, development, trade and environmental policies, should follow the same agenda". This is perhaps the core phrase in the ESS:

The best protection for our security is a world of well-governed democratic states. Spreading good governance, supporting social and political reform, dealing with corruption and abuse of power, establishing the rule of law and protecting human rights are the best means of strengthening the international order.

Such a holistic approach is best implemented via multilateralism: "We need to pursue our objectives both through multilateral cooperation in international organizations and through partnerships with key actors", according to the ESS. Only in cooperation with others can EU objectives be achieved peacefully, global challenges be successfully addressed, and complex issues be comprehensively tackled. "The development of a stronger international society, well functioning international institutions and a rule-based international order is our objective", declares the ESS under the heading of "effective multilateralism". Multilateralism is "effective" to the extent that the ensemble of regimes, mechanisms and institutions manages to provide access to the core public goods to citizens worldwide.

In spite of its misleading title, the ESS has a broad scope, integrating all external policies, not just CSDP or even CFSP, but all relevant Community policies as well. It certainly is a document that operates at the strategic level - but it is only a partial strategy. Starting from an analysis of the global environment, the ESS outlines three so-called strategic objectives ("addressing the threats", "building security in our neighbourhood", and "effective multilateralism"), and then draws some implications for the means. Yet under the heading of strategic objectives, the ESS mostly tells us how to do things- the ESS is much vaguer on what to do. This definition of an approach does constitute an important strategic choice, but the ESS is incomplete in terms of objectives, because to start with it is not clear about the values and interests to be defended. The 2008 Report on the Implementation of the European Security Strategy failed to rectify this. A grand strategy must necessarily be translated into sub-strategies and then policies for it to be put into action, but the three strategic objectives have proved too broad, and Member States far too hesitant to act upon the strategy that they have adopted, to generate clear priorities. Without clear objectives, strategic actorness is difficult to achieve.

\subsection{A Strategic Actor?}


In one sense the ESS has met and even surpassed expectations: it has not disappeared (Biscop 2009). Quite the contrary, it is very much present, as national and EU officials habitually refer to it when having to explain to various publics how the EU sees its role in the world. The ESS has been very important therefore in forging the EU's identity as an international actor. Certainly outside the EU, it is often taken at face value: a document adopted unanimously by the Heads of State and Government, with the word strategy in the title - that must be important.

In another sense, however, expectations have been disappointed: the ESS has not had sufficient influence on actual EU policies. This is difficult to measure, precisely because the ESS is more about how to do things than about what to do. And as to a large extent the ESS is the codification of an existing approach, the EU is implementing it just by continuing what it was already doing. Also, a number of strategies and policies have been adopted - on the Neighbourhood, Africa, terrorism, weapons of mass destruction etc. - which de facto function as "sub-strategies" to the ESS and thus, as they are put into action, implement the ESS even when not explicitly referring to it. As a result, it appears that the grand picture which the ESS presented somehow got lost again, in spite of its implicit presence. Although continuing to refer to the ESS in public forums, officials did not seem to use it actively in day-to-day activities. Nor was there a bureaucratic necessity for them to do so, as no follow-up mechanism was created to monitor implementation, and no deadline set by which to report back to the European Council. At the same time as adopting the ESS the European Council had defined four priority areas of implementation "effective multilateralism" with the UN at the core, terrorism, the Middle East, and BosniaHerzegovina - but it never got back to those in that context. It did appear that in the beginning some Member States, as well as the institutions, made good tactical use of the ESS in order to push proposals in the Council, but that too did not last.

Thus, many of the "policy implications" which the ESS calls for - to become "more active", "more capable", and "more coherent" - have yet to materialize. Since adopting the ESS, the EU has not become markedly more proactive, particularly not as regards the CSDP. The EU is active, witness: the contribution of 8,000 European blue helmets to UNIFIL in 2006; the EU Monitoring Mission in Georgia, deployed at record speed on 1 October 2008 after President Sarkozy brokered the Six-Point Agreement between Moscow and Tbilisi; EULEX Kosovo, deployed in December 2008 in spite of Member States' divisions about the recognition of Kosovo independence; and EU NAVFOR Somalia, deployed in the same month against piracy off the Somali coast. If it had not been for the EU, most Member States would in all probability not have had a policy at all on these issues. But the EU stance is mostly reactive, initial action is seldom followed up sufficiently, and too often the EU does not act at all. The key factor is the willingness of the Member States to act through the EU rather than individually, but more systematic reference to the ESS could at least help to stimulate joint action.

Fully-fledged strategic actorness would demand as a precondition a much clearer definition of priorities and objectives. With regard to CSDP, EU interests and objectives in a specific region should determine to which extent the EU will contribute to, or even take the lead in conflict resolution and crisis management, through diplomatic, civilian and military instruments. If the EU's engagement for global peace and security can be stepped up, there are, sadly, too many 
conflicts and crises for the EU to deal effectively with all of them, certainly in a leading role. Therefore, as the 2008 Implementation Report states, "We need to prioritise our commitments, in line with resources". Here EU strategic thinking is the least explicit. There is a missing link between the vague ambition expressed in the ESS - "to share in the responsibility for global security" - and the practice of CSDP operations and capability development.

First of all, there is not even consensus about which tasks or types of operations the EU can undertake. Most Member States do put their forces in harm's way, for national and NATO operations or coalitions of the willing. Yet although legally the EU's Petersberg Tasks include operations at the high end of the spectrum of violence, politically the Member States are still extremely divided over the use of force under the EU flag.

Secondly, no priority regions and scenarios have been defined, in function of Europe's vital interests: where and why will the EU deploy troops and perhaps even go to war? Because of its proximity, the neighbourhood logically appears as a clear priority, where the EU should not only be active but also take the lead. In the ESS "Resolution of the Arab/Israeli conflict is a strategic priority" - although that clear statement does not necessarily translate into proactive engagement - and the Implementation Report adds that "We need a sustained effort to address conflicts in the Southern Caucasus, Republic of Moldova and between Israel and the Arab States". But if the neighbourhood is a clear geographic priority, it is less clear in which types of contingencies the EU will undertake which type of action. Whether the "broader neighbourhood", including Central Asia and the Gulf, is a priority as well should also be debated. Next to the neighbourhood, only Iran is singled out as a priority, and the EU has indeed been "at the forefront of international efforts to address Iran's nuclear programme", as the Report states. Other conflicts are mentioned in the ESS: "Problems such as those in Kashmir, the Great Lakes Region and the Korean Peninsula impact on European interests directly and indirectly, as do conflicts nearer to home, above all in the Middle East" - whether that implies the EU should actively contribute to their resolution is not clear at all. Sub-Saharan Africa has been an important area of focus for CSDP, though the strategy behind it is not always clear; e.g. if the EU twice intervened in the DRC at the request of the UN, why was the third request refused? This demonstrates that without strategy, it is difficult to define what success of an operation means. Securing Europe's lines of communication with the world, of which the operation off Somalia is an example, is a more obvious priority (Rogers 2009). Finally, the collective security system of the UN, and therefore of the EU, as its main supporter and with two permanent members of the Security Council in its ranks, appears as a priority. Even though it cannot always play a leading role, the EU must shoulder its share of the responsibility for global peace and security

Finally, there is no clarity on the scale of the effort to be devoted to these priorities. Quantitatively, CSDP is based on the 1999 Helsinki Headline Goal, i.e. 60,000 troops, but this has been overshadowed by the much more limited battlegroup project (Lindström 2007). The actual availability of the forces declared cannot be assessed, as they are not pre-identified and Member States have mostly declared similar numbers to NATO as well. If all ongoing CSDP, NATO, UN and national operations in which EU Member States participate are counted, Europe today deploys more than 80,000 troops, but EU Member States obviously cannot mobilize 60,000 additional troops for expeditionary operations. But even the combined CSDP and NATO 
level of ambition, even if collective defence is taken into account, still falls far short of the total combined armed forces at the disposal of the EU-27: 2 million troops. There is as yet no clear vision of how many of those Europe really needs.

EU strategy, at the level of the ESS, ought to define Europe's ambition as a global security actor, which could then in turn inform a specific military or civil-military strategy or "white book" for CSDP. As Member States have but a single set of forces, the question is not what the CSDP level of ambition is and what that of NATO: the question is what the EU, as the political expression of Europe and as a comprehensive foreign policy actor, wants to contribute as a global security provider, regardless of whether a specific operation is undertaken under CSDP or NATO (or UN) command. It is in the EU, therefore, that Member States logically ought to take the primary political decision whether or not to act in a given situation. If their decision entails military action, the secondary step is to select the organization through which to act - NATO, CSDP, the UN, the OSCE, or an ad hoc coalition - which will always be a tailored solution, in function of which partners want to go along and which organization is best suited for the case at hand. It is in the EU too that Member States can build more deployable forces, by various forms of cooperation and pooling between Europeans, and which will be available for all of the potential frameworks for operations.

\subsection{A Strategic Culture?}

However, when discussing strategic actorness, it is important to also appreciate the fact that, like a state or any other actor, the EU does not and cannot operate outside a fairly stable ideational context or culture that constrains and facilitates certain actions. This may help us understand some of the strategic choices made. After 40 years of NATO dominance, the end of the Cold War spurred some essential changes to the European security environment that together pushed in the direction of a heavier security role for the EU. At the same time, the EU carried forward a strong awareness of its origins as a project for peace, having risen from the ashes of two world wars. This has necessarily put some constraints on the way that a security policy was to be accommodated in the EU. In other words, the EU's security and defence policy was conceived, has evolved and continues to evolve inside a quite specific context; or what, in the strategic literature, is often referred to as a strategic culture (see e.g. Snyder 1977; Lord 1985; Booth and Trood 1999; Klein 1988; Johnston 1998; Farrell 2005; Booth 1979; Gray 1981; Pipes 1977). ${ }^{1}$

Going back some 30 years, the strategic culture debate has evolved in step with scholarly developments and changes in the security environment, proving its endurance in the recent revival of the concept as part of the contemporary European security debate. The appeal of the concept rests with its inherent potential for incorporating a range of more or less elusive ideational factors, such as history, norms, identity, values and ideas, in explanations of why certain states - and, more recently, institutions - (are able to) act the way they do. Herein we also find strategic culture's weak spot: the term means different things to different people. Or as Colin Gray remarks: "The ability of scholars to make a necessarily opaque concept like strategic culture even less penetrable is truly amazing" (Gray 2006, p. 9). Indeed, to some the idea of a

\footnotetext{
${ }^{1}$ For a more detailed breakdown of how the concept of strategic culture has evolved, see Norheim-Martinsen (2007) or Neumann and Heikka (2005).
} 
European strategic culture represents something of a contradiction in terms, because the persistence of heavily ingrained national strategic cultures would seem to render it impossible (Hyde Price 2004; Matlary 2006; Rynning 2003). To others, the idea that national strategic cultures may coexist with a European one seems wholly uncontroversial (Cornish and Edwards 2001, 2005; Howorth 2007). However, the bottom line is that if the EU uses military force or other instruments in pursuit of some notion of collective European interests or ends, it does so de facto within some kind of context or (a) strategic culture(s).

It makes little sense, therefore, to state that the EU has or has not acquired a strategic culture. In fact, the question whether strategic cultures exist or not, or more correctly whether they can explain strategic behaviour, has for all means and purposes been left behind, following a protracted principled debate throughout the 1990s (Gray 1999; Johnston 1995, 1998, 1999). Looking back at the debate, Colin Gray, one of its key proponents, rather tellingly deems it "rather foolish since there is general agreement on the content of the subject and, roughly, on how it functions" (Gray 2006, p. ii). Instead the more recent debate - albeit not always mirrored in the one on $E U$ strategic culture - has settled around the original (first generation) understanding of strategic culture as context, focusing instead on the observable and unobservable components of strategic culture(s).

Some draw attention to the "self-regulating policies and practices which give active meaning to the foundational elements [of a strategic culture]" (Longhurst 2000, p. 305), while others look into the dynamic interplay between "discourse and practice" (Neumann and Heikka 2005). There has also been a growing interest in the relationship between "culture" and "strategic narratives" (see e.g. Arquilla and Ronfeldt 2001; Freedman 2006; Kaldor, Martin, and Selchow 2007). Lawrence Freedman contends, for example, that:

Culture, and the cognition which it influences, is rarely fixed but in a process of development and adaptation [...]. It is in this context that the concepts of narratives compelling story lines which can explain convincingly and from which inferences can be drawn - becomes relevant.

As he goes on, in a contemporary security environment, the role of strategic narratives has become even more salient, since the wars of ideas that take place in the media and the public domain is often as important as the ones on the ground (Freedman 2006, pp. 22-26). Security strategies, strategy papers, Defence White Papers and the like, as the most deliberate expressions of strategic narratives, represent not merely, or perhaps even primarily, strategic guidelines, but documents for public consumption, deliberate efforts to legitimise future actions, and reconcile with or signal difference to the "other" as part of shaping one's own strategic identity. It is, therefore, necessary to also view the 2003 ESS and later documents in this perspective - as essentially elements of a strategic narrative intended to justify or "sell" the already maturing idea of CSDP as an inherent and natural part of an evolving EU.

The ESS proved that the EU need not be very different from a state in the way that is uses strategic narratives as a way to legitimise, expand or restrict the scope of its actions. As such, the document had a reach far beyond the short-term political context in which it was conceived. It 
was in itself a significant step in the constant reaffirmation and incremental evolution of an EU strategic culture. However, whether this amounts to what the ESS refers to as a "strategic culture that fosters early, rapid and when necessary, robust intervention" is questionable (ESS, p. 11). In this regard, one should note that an actor is not at will to change or mould a culture as she pleases. Strategic narratives (and cultures) are essentially conservative, since they need to be constructed out of ideas that are recognisable to and considered legitimate by their recipients (Parsons 2002). Nevertheless, the EU has been, perhaps more than most states, upon which centuries of history and traditions weigh heavily, in a position to reinvent its strategic narrative. Or as Martin Ortega points out, since it was created in a benign environment and was, therefore, not threat-based nor part of an attempt to compete militarily with other powers, it could be constructive rather than responsive (Ortega 2007, p. 93).

In fact, if we look at the overall storyline that the ESS conveys, it is striking how the document virtually leapfrogs over the Cold War as a reference point, especially given this event's essentiality for the creation of CFSP and later CSDP. Instead, it goes back to what Frank Schimmelfenning (2003, pp. 265-78) has referred to as the "founding myth" of European integration, the historical responsibility for creating lasting peace among democratic European states. As such, the ESS essentially restored an idea that had played a minor role in the integration process during the Cold War, by placing it at the heart of the forces that had "transformed relations between our states, and the lives of our citizens", with the result that Europe has never been "so prosperous, secure or free" (ESS, p. 1). Having successfully escaped the legacy of two devastating world wars, the logic goes, Europe should now "be ready to share in the responsibility for global security and in building a better world" (ESS, p. 1).

The reference can be seen as an attempt at pinning CSDP to the one uniting experience that the European states have in common, while offering an alternative to national strategic cultures. However, a question that has been frequently asked is whether it represents a strong enough rationale on which to build a shared and strong EU strategic culture. Adrian Hyde-Price (2004) argues that the unprecedented effect that the experience of war has traditionally had on national strategic cultures is exactly why such a common European strategic culture is unlikely to emerge. In a similar vein, Peter van Ham argues that the reference to the EU founding myth "breaks a pattern since historically war and violence have played a major part in state-formation" (van Ham 2005, p. 39; see also van Ham 2001). Or, as he goes on to state: "Without war 'we' hardly know who 'we' are".

In fact, in its absence of military references, the ESS presents a rather different rationale for a security strategy. Insofar as an important function of such a document is to preserve or strengthen a robust strategic culture, the peaceful starting point for the ESS represents a less solid cultural building block, so to speak, when compared with the role that the experience of war has traditionally played in the shaping of national strategic cultures. Nevertheless, the European option clearly has its appeal, as reflected, for example, in the re-education of the German public and Europe at large over the course of the 1990s, leading to the general acceptance and even encouragement of German armed forces being used for purposes other than territorial defence, even as it challenges supposedly deep-rooted national strategic cultures built on the experience of suffering two world wars (Howorth 2004). It can be argued, therefore, that the apparent 
preference given to non-military instruments by the EU is not only rooted in disagreement between the Member States regarding the military dimension of CSDP, but also in distinctive features of a European strategic culture, which represents, as such, at least partly a conscious or path dependent European choice. On the one hand, most Member States do seem to appreciate that military power is necessary for lifting the EU's weight on the world stage, and that engaging in military operations is a rational way to boost its hard power. Yet, on the other hand, they are well aware of the fact that the move into the military realm in certain respects does conflict with the very image of the EU and the ideas, values and norms that uphold it. In that sense, acting militarily, but well within the overarching conflict preventive (read: more benign) parameters, has become an end in itself and a way to legitimise military force as an inherent and natural part of an EU strategic culture.

Hence, when read as a traditional strategy, the ESS does not immediately or principally lend itself to the usual strategic ends/means teleology. It is arguably better understood as the product of a logic of appropriateness rather than of a logic of consequences - i.e. how the EU acts becomes and end in itself (cf. March and Olsen 1989). Even without a clear set of objectives or ends, therefore, it may still be possible for the EU to achieve a sense of strategic actorness albeit perhaps not in the longer run. CSDP is, indeed, a pertinent example of how culture binds rationality. We could thus add a notion to the 30-year-old strategic culture dichotomy of rational man vs. national man, namely that of supranational man: i.e. when acting within the auspices of CSDP, all actors are induced or compelled to do so in a way that falls within certain premeditated conceptions of how the EU as a collective should behave. That is, the way in which to act has become a source of a European "self". The "other", as the omnipresent contrast against which an identity is often shaped (cf. Campbell 1992; van Ham 2001, 2005), is in this logic to be found across the Atlantic.

At the heart of this EU strategic culture lies the broad, multidimensional or holistic approach to security described above. However, it is worth reflecting on the fact that the idea of a holistic approach was, in 2003, certainly not new or unique to the EU (Biscop 2008). Organisations such as the UN and the OSCE had been promoting comprehensive security already during the Cold War, while the EU mostly played the part of the follower. It was only in the mid-1990s that the EU also started to reform its structures for conflict prevention and crisis management, joining the "comprehensive trend" that gained momentum in the first decade after the Cold War (Biscop 2008; Schneckener 2002). Eventually the comprehensive security logic received something of an omnipresence in EU documents, as reflected, for example, in the Stability Pact for Central and Eastern Europe, as well as in actual policies, such as the Stability and Association Process(es) (SAP) in the Balkans and the Euro-Mediterranean Partnership programme (EMP). The acknowledgement of the need for comprehensive approaches was, in turn, gradually translated into a potential asset for the EU - i.e. something that the Union is "particularly well equipped" to do (ESS, p. 7). Incidentally the lack of preparedness of the US-led coalition in Iraq, and later of NATO in Afghanistan, for dealing with the massive challenges that emerged in the wake of the war, and the dawning of the fact that a "war" on terror could not be won militarily, placed the EU firmly in the driver's seat of an ongoing comprehensive trend. 
As such, from being seen as a sign of weakness (see Kagan 2003), this comprehensive approach has become a rather powerful focal point around which to build a European strategic culture. First, it fits well into the conventional narrative of the European integration process as a project for peace by underlining the military dimension's secondary nature - i.e. the EU prefers to act using its traditional strengths as a non-military power, and has successfully done so in the past "making a reality of the vision of a united and peaceful continent" (ESS, p. 1), but must also be able to use force to tackle emerging crises in its neighbourhood and beyond. It has a stated nonaggressive purpose and has allowed the EU, at least until recently, to portray itself, in the words of Richard Gowan (2009), as a "benign interventionist", perhaps not devoid of, but somewhere above the national interest. Secondly, acting comprehensively represents a source of a strategic "self" for a peaceful Europe without enemies. As such, a contrasting "other" is typically found in the United States, but without having to resort to the kind of negative stereotype imaging of an adversary that has often dominated national strategic cultures in the past. Thirdly, the comprehensive approach underlines that CSDP represents something different and that it does not duplicate NATO. That the term comprehensive approach, as a concept albeit not an idea, was first associated with NATO was then perhaps somewhat ironic, but the way in which the EU has taken ownership of the term underlines that the EU is inherently and intuitively better equipped to carry it through. As such, it represents also a potential comparative advantage for the EU, or a European way of warfare that has suddenly come into fashion with the need for post-conflict stabilisation and reconstruction in places such as the Balkans, Central Africa, Iraq and Afghanistan. As a strategic narrative, therefore, the ESS could be seen as a first step in a rather successful "corporate strategy" for selling the idea of CSDP and building an EU strategic culture.

\section{Conclusion}

In applying the strategic perspective to the EU, this chapter has assessed three core elements: EU strategy (the ESS), its actorness, and its strategic culture. Because it lacks a clear indication of objectives, the ESS cannot be considered a fully-fledged strategy. Nevertheless, the EU has been very active through its CSDP, witness the number of operations. Looking at strategic culture helps appreciate how this sense of strategic actorness has been achieved by the EU without the clear set of objectives one would normally expect to see in a strategy (in casu the ESS). Acting European has become a source of strategic identity for the EU and an end in itself.

A question is, however, whether the EU's strategic narrative will be challenged by competing, less appealing narratives if the EU should fail to produce ways, means and results that fall within the inevitable constraints and expectations that come with the narrative (cf. Gilbert 2008). Strategy is, after all, not a one way street, but a product of a dynamic interplay between discourses or narratives, on the one hand, and strategic conduct, on the other. A strategic narrative relates to and codifies ideas and values that exist "out there" already as the cultural boundaries inside which the strategic actor operates. The narrative can be constructive, in the sense that these boundaries can be incrementally and cautiously shifted. Yet a complex multilevel actor such as the EU in particular - as, indeed, any actor - has limited control over how the narrative plays out when confronted with other actors and real-world events. A strategic decision, Carl von Clausewitz reminds us, will always have both intended and unintended 
consequences, which reflect back on the strategic actor in ways over which it has limited control. A decision to intervene in one situation at one point creates expectations or precedents for similar situations in the future. Likewise, a repeated focus on the EU's unique credentials and potentials as a holistic or comprehensive actor will create an expectation that it will also act decidedly comprehensively, and invite criticism if it fails to produce ways, means and results that reflect this.

With regard to CSDP specifically, as Howorth (2010b, p.3) puts it, "The record to date is nothing to be ashamed of. Every operation so far undertaken has its underlying raison d'être. None has been embarked on flippantly or for the wrong reasons". But until now CSDP operations, while all successful, have mostly been of smaller scale and of limited duration. Although the EU should not seek the occasion just for the sake of it, the question can legitimately be asked whether the EU ought not also be capable of, and when necessary, actually decide to assume responsibility for a larger-scale CSDP-operation of longer duration. The risk of engaging in such a venture is that failure might harm further development of CSDP. The flip side of the coin is that never engaging in such a venture would undermine the credibility of CSDP. This would also harm further development of CSDP.

Whereas "constructive ambiguity", in the words of Francois Heisbourg (2000), for a while was seen as a sufficient guiding star for a CSDP in need of a purpose, this is simply no longer an option for a strategic actor that has in due course carved a rather specific role for itself alongside NATO and the UN. If the EU truly wants to become an effective strategic actor, in other words a power, it will have to set explicit priorities for CSDP, as the starting point for a proactive policy. A security and defence strategy or white book at the EU level: a call for strategic perspective if ever there was one.

Prof. Dr. Sven Biscop is Director of the Europe in the World Programme at Egmont - The Royal Institute for International Relations in Brussels and Visiting Professor at the College of Europe in Bruges and at Ghent University. He is a member of the Executive Academic Board of the European Security and Defence College and a Senior Research Associate of the Centre for European Studies at the Renmin University of China in Beijing.

Dr. Per M. Norheim-Martinsen is a Senior Research Fellow at the Norwegian Defence Research Establishment (FFI).

Arquilla, John, and David Ronfeldt. 2001. Networks and Netwars: The Future of Terror, Crime and Militancy. Santa Monica, CA: RAND Corporation.

Ayoob, Mohammed. 1995. The Third World Security Predicament: State Making Regional Conflict and the International System. Boulder, Colo.: Lynne Rienner.

Bailes, Alyson. 2005. The European Security Strategy - An Evolutionary History. Policy Paper 10. Stockholm: SIPRI.

Baylis, John, James Wirtz, Eliot Cohen and Colin S. Gray, eds. 2002. Strategy in the Contemporary World. An Introduction to Strategic Studies. Oxford: Oxford University Press. 
Betts, Richard K. 1997. Should Strategic Studies Survive? World Politics 50:7-33.

Biscop, Sven. 2005. The European Security Strategy. A Global Agenda for Positive Power. Aldershot: Ashgate.

. 2008. The European Security Strategy in context: a comprehensive trend. In The EU and the European Security Strategy: Forging a Global Europe, edited by S. Biscop and J. J. Andersson. London: Routledge.

- 2009. Odd Couple or Dynamic Duo? The EU and Strategy in Times of Crisis. European Foreign Affairs Review 14 (3): 367-384.

Biscop, Sven and Jan Joel Andersson, eds. 2008. The EU and the European Security Strategy: Forging a Global Europe. London: Routledge.

Booth, Ken. 1979. Strategy and Ethnocentrism. New York: Holmes and Meier.

Booth, Ken, and Russel Trood. 1999. Strategic Cultures in the Asia-Pacific Region. London: Macmillan.

Bull, Hedley. 1982. Civilian Power Europe: A Contradiction in Terms? Journal of Common Market Studies 21 (1-2).

Buzan, Barry, Jaap de Wilde, and Ole Waever. 1998. Security: A New Framework for Analysis. Boulder, Colo.: Lynne Rienner.

Campbell, David. 1992. Writing Security: United States Foreign Policy and the Politics of Identity. Minneapolis: University of Minnesota Press.

Clausewitz, Carl von. 1976 [1832]. On War. Princeton: Princeton University Press, translation by Michael Howard and Peter Paret.

Cornish, Paul, and Geoffrey Edwards. 2001. Beyond the EU/NATO dichotomy: the beginnings of a European strategic culture. International Affiars 77 (3):587-603.

2005. The Strategic Culture of the European Union: a progress report. International Affairs 81 (4):801-820.

Deudney, Daniel. 1990. The Case Against Linking Environmental Degradation and National Security. Millennium 19 (3):461-76.

Duchêne, Francois 1972. Europe in World Peace. In Europe Tommorrow, edited by R. Maine. London: Fontana/Collins.

Engelbrekt, Kjell, and Jan Hallenberg, eds. 2008. The European Union and Strategy. An Emerging Actor. London: Routledge.

European Council. 2003. A Secure Europe in a Better World: European Security Strategy. Endorsed by the European Council, Brussels, 11-12 December 2003.

Farrell, Theo. 2005. Strategic Culture and American Empire. The SAIS Review of International Affairs 25 (2).

Freedman, Lawrence. 1998. International Security: Changing Targets. Foreign Policy 110:48-63. . 2006. The Transformation of Strategic Affairs. Adelphi Paper 379, IISS, London: Routledge.

Gilbert, Mark. 2008. Narrating the Process: Questioniing the Progressive Story of European Integration. Journal of Common Market Studies 46 (3):641-662.

Gowan, Richard. 2009. Good Intentions, Bad Outcomes 2009 [cited January-February 2009]. Available from http://www.esharp.eu/issue/2009-1/Viewpoint-Good-intentions-badoutcomes.

Gray, Colin. 1981. National Styles in Strategy: The American Example. International Security 6 (2):21-47. 
1999. Modern Strategy. New York: Oxford University Press.

1999. Strategic culture as context: the first generation of theory strikes back. Review of International Studies 25:49-69.

2006. Out of the Wilderness: Prime Time for Strategic Culture. Fort Belvoir (Va.): Defence Threat Reduction Agency.

Grevi, Giovanni. 2009. Institutional Change and Continuity in the CFSP and ESDP. In Paper presented at the 50th Annual ISA Convention. New York: 15-18 February.

Haftendorn, Helga. 1991. The Security Puzzle: Theory-Buliding and Discipline-Building in International Security. International Studies Quarterly 35 (1):3-17.

Heisbourg, Francois. 2000. Europe's Strategic Ambitions: The Limits of Ambiguity. Survival, 42 (2): 5-15.

Heisbourg, François. 2004. The "European Security Strategy" is not a Security Strategy. In $A$ European Way of War edited by Steven Everts et al. Londen: Centre for European Reform.

Heiselberg, Stine. 2003. Pacifism or Activsim: Towards a Common Strategic Culture within the European Security and Defence Policy? Danish Insitute for International Studies: IIS Working Paper 2003/4.

Hill, Christopher. 1993. The Capability-Expectations Gap, or Conceptualising Europe's International Role. Journal of Common Market Studies 31:305-28.

Howard, Michael. 1983. The Forgotten Dimensions of Strategy. In The Causes of Wars, edited by M. Howard. London: Temple Smith.

Howorth, Jolyon. 2004. Discourse, Ideas, and Epistemic Communities in European Security and Defence Policy. West European Politics 27 (2):211-234.

. 2007. Security and Defence Policy in the European Union. Houndmills, Basingstoke: Palgrave.

—. 2010a. The EU as a Global Actor: Grand Strategy for a Global Grand Bargain? Journal of Common Market Studies 48 (3): 455-474.

- 2010b. Strategy and the Importance of Defence Cooperation among EU Member States. Security Policy Brief 12. Brussels: Egmont - Royal Institute for International Relations.

Huysmans, Jef. 1995. Migrants as a Security Problem: Dangers of "Securitising" Social Issues. In Migration and European Integration: The Dynamics of Inclusion and Exclusion, edited by R. Miles and D. Thränhardt. London: Pinter.

1998. Security! What do you mean?: From Concept to Thick Signifier. European Journal of International Relations 4 (2).

Hyde Price, Adrian. 2004. European Security, Strategic Culture and the Use of Force. European Security 13 (4):323-343.

Johnston, Alastair Iain. 1995. Thinking About Strategic Culture. International Security 19 (4).

- 1998. Cultural Realism: Strategic Culture and Grand Strategy in Chinese History. Princeton: Princeton University Press.

- 1999. Strategic Culture Revisited: a reply to Colin Gray. Review of International Relations 25 (3).

Kagan, Robert. 2003. Of Paradise and Power: America and Europe in the New World Order. New York: Knopf.

Kaldor, Mary, Mary Martin, and Sabine Selchow. 2007. Human Security: A New Strategic Narrative for Europe. International Affairs 83 (2):273-288. 
Katzenstein, Peter J. 1996. The Culture of National Security. Norms and Identity in World Politics. New York: Columbia University Press.

Klein, Bradley S. 1988. Hegemony and Strategic Culture: American Power Projection and Alliance Defence Politics. Review of International Studies 14 (2).

Krause, Keith, and Michael Williams. 1997. Critical Security Studies. Minneapolis: University of Minnesota Press.

Liddell-Hart, Basil. 1967. Strategy: The Indirect Approach. London: Faber.

Lindström, Gustav. 2007. Enter the EU Battlegroups. Paris: EU Institute for Security Studies, Chaillot Paper No. 97.

Longhurst, Kerry. 2000. Strategic Culture. In Military Sociology: The Richness of a Discipline, edited by G. Kümmel and A. D. Prüfert. Baden Baden: Nomos.

Lord, Carnes. 1985. American Strategic Culture. Comparative Strategy 5 (3):269-93.

Manners, Ian. 2006. Normative Power Europe Reconsidered: Beyond the Crossroads. Journal of European Public Policy 13 (2):182-199.

. 2009. Europe and the World. London: Palgrave.

Manners, Ian, and Richard G. Whitman. 2000. The Foreign Policies of the European Union Member States. London: Macmillan.

March, James, and Johan P. Olsen. 1989. Rediscovering Institutions: The Organizational Basis of Politics. New York: Free Press.

Martinsen, Per Martin. 2004. Forging a Strategic Culture - Putting Policy into the ESDP. Oxford Journal on Good Governance 1 (1):61-66.

Matlary, Janne Haaland. 2006. When Soft Power Turns Hard: Is an EU Strategic Culture Possible? Security Dialogue 37 (1):105-21.

Meyer, Christoph O. 2006. The Quest for a European Strategic Culture: A Comparative Study of Strategic Norms and Ideas in the European Union. Basingstoke: Palgrave Macmillan.

Neumann, Iver B., and Henrikki Heikka. 2005. Grand Strategy, Strategic Culture, Practice. The Social Roots of Nordic Defence. Cooperation and Conflict 40 (1):5-23.

Norheim-Martinsen, Per Martin. 2007. European Strategic Culture Revisited: The Ends and Means of a Militarised European Union. Defence and Security Studies 1 (3, September 2007).

Ortega, Martin. 2007. Building the Future: The EU's Contribution to Global Governance. EU Institute for Security Studies: Chaillot Paper no. 100.

Parsons, Craig. 2002. Showing Ideas as Causes. The Origins of the European Union. International Organization 56 (1):47-84.

Pipes, Richard. 1977. Why the Soviet Union Thinks It Could Fight and Win a Nuclear War. Commentary 1:21-34.

Rogers, James. 2009. From Suez to Shanghai: The European Union and Eurasian Maritime Security. Ocasional Paper 77. Paris: EU Institute for Security Studies.

Rynning, Sten. 2003. The European Union: Towards a Strategic Culture? Security Dialogue 34 (4):479-496.

Schimmelfenning, Frank. 2003. The EU, NATO and the Integration of Europe: Rules and Rhetoric. Cambridge: Polity Press.

Schneckener, Ulrich. 2002. Theory and Practice of European Crisis Management: Test Case Macedonia. European Yearbook of Minority Issues 1 (2001/02). 
Smith, Karen E. 2006. The End of Civilian Power Europe: A Welcome Demise or a Cause for Concern? International Spectator 35 (2): 11-28.

Snyder, Jack L. 1977. The Soviet Strategic Culture: Implications for Limited Nuclear Operations. Santa Monica, CA: R-2154-AF, September 1977.

Stavridis, Stelios 2001. Militarising the EU: the Concept of Civlian Power Revisited. International Spectator XXXVI (4).

Strachan, Hew. 2005. The Lost Meaning of Strategy. Survival 47 (3):33-54.

Telo, Mario. 2006. Europe: A Civilian Power? European Union, Global Governance, World Order. Basingstoke: Palgrave.

Toje, Asle. 2005. The 2003 European Union Security Strategy: A Critical Appraisal. European Foreign Affairs Review 10 (1): 117-133.

- 2008. The EU, NATO and Strategic Culture: Renegotiating the Transatlantic Bargain. London Routledge.

van Ham, Peter. 2001. Europe's Postmodern Identity: A Critical Appraisal. International Politics 38 (1):229-252.

- 2005. Europe's Strategic Culture and the Relevance of War. Oxford Journal of Good Governance 2 (1):39-43.

Waever, Ole. 1995. Securitization and Desecuritization. In On Security, edited by R. D. Lipschutz. New York: Columbia University Press.

- 1998. Insecurity, security and asecurity in the West European non-war community. In Security Communities, edited by E. Adler and M. Barnett. Cambridge: Cambridge University Press.

Walt, Stephen. 1991. The Renaissance of Security Studies. International Studies Quarterly 35 (2).

- 1998. International Relations: One World, Many Theories. Foreign Policy 110, Spring.

Wendt, Alexander. 1992. Anarchy Is What States Make of It: The Social Construction of Power Politics. International Organization 46 (2).

Whitman, Richard G. 1998. From Civilian Power to Superpower? The International Identity of the European Union. London: Macmillan.

Wyllie, James H. 2006. Measuring up. The Strategies as Strategy. In Security Strategy and Transatlantic Relations edited by Roland Dannreuther and John Peterson. London: Routledge. 